\title{
Invisible Storytellers
}


This page intentionally left blank 


\section{Invisible Storytellers}

Voice-Over Narration in American Fiction Film

\section{Sarah Kozloff}

University of California Press

Berkeley / Los Angeles / London 
This book is a print-on-demand volume. It is manufacturcd using toner in place of ink. Type and images may be less sharp than the same material secn in traditionally printed University of California Press editions.

University of California Press

Berkeley and Los Angeles

University of California Press, Lid.

London, England

(C) 1988 by

The Regents of the University of California

Library of Congress Cataloging-in-Publication Data

Kozloff, Sarah

Invisible storytellers.

Filmography: $p$.

Bibliography: $p$.

Includes index.

1. Moving-picture plays-History and criticism.

2. Moving-pictures-United States. 3. Narration

(Rhetoric) I. Title: Voice-over narration in American fiction film. II. Title.

PN1995.K69 $1988 \quad 791.43^{\prime} 0973 \quad 87-12461$

ISBN 0-520-05861-5 (alk. paper)

Printed in the United States of America

The paper used in this publication meets the minimum requirements of ANSI/NISO Z39.48-1992 (R 1997)

(Permanence of Paper). $\infty$ 
To my brother, Daniel Kozloff, who used to read me stories and take me to movies 
This page intentionally left blank 